\title{
Evaluation of Antidiarrheal Activity of the Ethanol Extract Leucaena leucocephala (Lam) de Wit Seed
}

\author{
Saddam Husein ${ }^{1}$, Marline Nainggolan $^{1 *}$, Yuandani Yuandani $^{2}$, Irzal Fanany ${ }^{1}$ \\ ${ }^{1}$ Department of Pharmacy Biology, Faculty of Pharmacy, University of Sumatera Utara, Medan, Sumatera Utara, Indonesia; \\ ${ }^{2}$ Department of Pharmacology, Faculty of Pharmacy, University of Sumatera Utara, Medan, Sumatera Utara, Indonesia
}

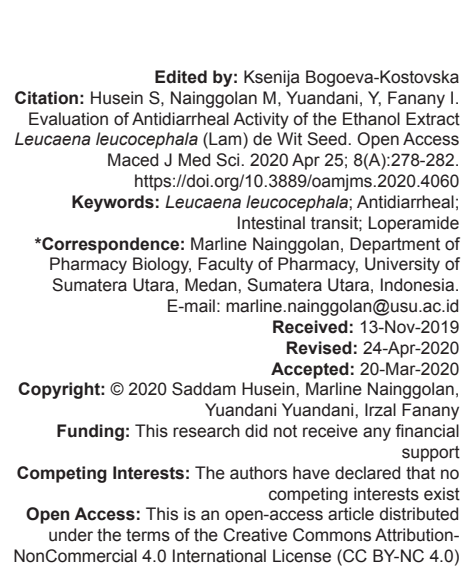

Introduction

Diarrhea is a disease whose incidence is still quite high, according to the WHO there are 2 billion cases of diarrheal disease that occur every year in the world and 1.9 million children are declared dead due to diarrhea every year according to data obtained from UNICEF. The total data obtained represent $18 \%$ of all deaths that occur in children under 5 years, which means more than 5000 children almost die every day due to diarrhea. There are $78 \%$ of cases of diarrheal disease that occurs from all child deaths due to diarrhea in Africa and Southeast Asia [1]. Diarrheal disease causes more than 5-8 million deaths worldwide each year at the age of $<5$ years [2].

Diarrhea is a common problem for people who suffer from frequent and watery stool. Most cases of diarrhea are caused by disruption of water and electrolyte transport in the intestine. The mechanism of diarrhea occurs due to increased intestinal osmotic pressure (thus causing water retention in the lumen); electrolyte secretion which causes excessive water in the intestinal lumen; fluid and protein exudation out of the mucosa; and changes in intestinal peristaltic thereby accelerating transit. This usually occurs from various interrelated processes, which cause an increase in stool volume and weight accompanied by percent water content [3]. Most cases of diarrhea due to intestinal irritation by pathogens that affect the intestinal mucosal layer can result in increased secretory yield. This irritation affects intestinal peristaltic increment which causes a lot of fluid and electrolyte to be wasted. Individuals who have severe diarrhea can die [4].

The plant Leucaena leucocephala (Lam.) de Wit according to the previous research has various activities in medicine such as antidiabetic, antioxidant, antibacterial, and cancer preventive [5], [6]. In Thailand L. leucocephala leaves are used for diarrhea medicine[7]. The people of Mexico and Zimbabwe utilize L. leucocephala leaves for animal feed which increase livestock milk production [8], [9]. In Peru, bark and flowers of L. leucocephala are used as antiseptics [10]. L. leucocephala contains alkaloids, saponins, flavonoids, tannins, mimosin, leukanin, proteins, fatty acids, and fiber [6], [10], [11], [12]. Flavonoids also have an antidiarrheal effect by inhibiting intestinal motility thereby reducing fluid and electrolyte secretion [13]. Tannin compounds are as astringent, tannin works as 
astringent by wrinkling the surface of the small intestinal mucosa and stimulating water absorption in the lumen. This condition can ultimately reduce diarrhea [14]. This study was constructed and aimed to investigate the ethanol extract of $L$. leucocephala seeds as antidiarrheal using two different methods; these include castor oilinduced diarrhea and intestinal transit methods.

\section{Materials and Methods}

\section{Plant collection and Extraction}

The seeds of $L$. leucocephala (Leguminosae) were collected from Batang Kuis, Deli Serdang, Sumatera Utara, Indonesia). The plant identified and authenticated by the Indonesian Institute of Sciences (LIPI) Bogor Indonesia (approval number 904/IPH.1.01/If.07/V/2019). The preparation of $\mathrm{L}$. leucocephala semen extract was carried out by maceration of $1200 \mathrm{~g}$ of simplisia powder with $80 \%$ ethanol solvent. Soak for the first $6 \mathrm{~h}$ while stirring occasionally, then let stand for $18 \mathrm{~h}$. Maserati are accommodated and then separated by sedimentation, then filtered. The search process is carried out twice. The Maserati were collected. Then, the filtrate was concentrated at $40 \pm 2^{\circ} \mathrm{C}$ in vacuum evaporator and thickened by heating in waterbath at $40 \pm 2^{\circ} \mathrm{C}$.

\section{Animals}

The use of rats was approved by the Animal Research Ethics Committees of Universitas Sumatera Utara. The experimental animals used were male white rats weighing $150-200 \mathrm{~g}$ divided into six groups and each group of five rats. Before being used, the rats were acclimatized for 7-14 days with the environmental conditions of the experiment with $12 \mathrm{~h}$ of light and $12 \mathrm{~h}$ of darkness.

\section{Castor oil-induced diarrhea}

Evaluation of antidiarrheal effects caused by castor oil is carried out with the method described by Yuandani and Nazira [15]. Rats were divided into several groups, which included negative controls, positive controls, and treatment groups. Before the investigation, all animals were not given food for $18 \mathrm{~h}$ but could consume water. Each rat was given $2 \mathrm{ml}$ castor oil, then after $1 \mathrm{~h}$ the rats were given $0.5 \% \mathrm{Na}-\mathrm{CMC}$ suspension ( $50 \mathrm{mg} / \mathrm{kg} \mathrm{BW}$ ) orally as a negative control group, loperamide suspension (1 $\mathrm{mg} / \mathrm{kg} \mathrm{BW}$ ) as a group positive control, and L. leucocephala extract (50, 100,200 , and $400 \mathrm{mg} / \mathrm{kg} \mathrm{BW}$ ) orally for each group. The rats were placed in cages which have been layered with weighted paper and observed every 30 min after treatment for $6 \mathrm{~h}$. The parameters observed include the onset of diarrhea, the frequency of diarrhea, the consistency and weight of stool and the duration of diarrhea.

\section{Intestinal transit method}

The anti-motility activity of extract was investigated using transit intestinal methods as described previously by Yuandani and Nazira [15]. The rat groups was divided into negative control, positive control, and treatment groups. Before the investigation, all animals were not given food for 18 $\mathrm{h}$ but could consume water. Each rat was given $2 \mathrm{ml}$ castor oil, then after $1 \mathrm{~h}$ the rats were given $0.5 \%$ $\mathrm{Na}-\mathrm{CMC}$ suspension (50 mg/kg BW), loperamide suspension (1 $\mathrm{mg} / \mathrm{kg} \mathrm{BW}$ ), and $L$. leucocephala extract $(50,100,200$, and $400 \mathrm{mg} / \mathrm{kg} \mathrm{BW})$ orally for each group and $1 \mathrm{ml}$ of Chinese ink was given orally 1 $\mathrm{h}$ after treatment. After $1 \mathrm{~h}$ was given Chinese ink, all animals were sacrificed by dislocation of the cervical vertebrae. Animals are dissected and their intestines are carefully removed. We measured intestinal length through which Chinese ink markers range from pylorus to ileocecal valve of each animal. Then from each animal calculated the percent of the distances traveled by Chinese ink markers the intestine length was calculated. The peristaltic index has been calculated using the following formula:

Peristaltic index $=\frac{\text { Distance traveled by chinese ink }}{\text { Total smallintestinelength }} \times 100$

\section{Statistical analysis}

Data from test observations analyzed using Statistical Package for the Social Sciences (SPSS). The data are presented as mean \pm standard error of the mean (SEM) and analyzed using a one-way analysis of variance (ANOVA) and followed by Tukey's post hoc test. $p<0.05$ was considered to be significantly different.

\section{Results}

\section{Castor oil-induced diarrhea}

Investigation of antidiarrheal activity induced by castor oil, the observed responses include the initial time of occurrence, frequency, duration of diarrhea, the weight, and consistency of stool. Table 1 shows that all doses of extracts were able to delay the onset of diarrhea compared with negative control. L. leucocephala at $400 \mathrm{mg} / \mathrm{kg} \mathrm{BW}(120.40 \pm 4.106)$ activity in delaying the onset of diarrhea was observed when compared to the positive control group $(118 \pm 3.980)$ had activity that was not significantly different loperamide $(p>0.05)$ 
Table 1: Activity of extract $L$. leucocephala seeds on diarrhea induced by castor oil

\begin{tabular}{|c|c|c|c|c|}
\hline No. & Treatment & Onset (minutes) & Frequency (times) & Duration (minute) \\
\hline 1. & $\mathrm{Na}-\mathrm{CMC} 0,5 \%$ & $56.60 \pm 3.059+$ & $6.80 \pm 0.374+$ & $285 \pm 5.394^{+}$ \\
\hline 2. & $\begin{array}{l}\text { Loperamide } \\
1 \mathrm{mg} / \mathrm{kg} \mathrm{BW}\end{array}$ & $118.80 \pm 3.980^{*}$ & $3.60 \pm 0.245^{\star}$ & $176.4 \pm 7.820^{*}$ \\
\hline 3. & $\begin{array}{l}\text { L. leucocephala } \\
\text { extract } 50 \mathrm{mg} / \mathrm{kg} \text { BW }\end{array}$ & $61.80 \pm 6.028^{+}$ & $6.20 \pm 0.374+$ & $256.40 \pm 6.096^{*,+}$ \\
\hline 4. & $\begin{array}{l}\text { L. leucocephala } \\
\text { extract } 100 \mathrm{mg} / \mathrm{kg} \mathrm{BW}\end{array}$ & $80.40 \pm 4.578^{*,+}$ & $5.60 \pm 0.510+$ & $220.40 \pm 4.675^{*^{*+}}$ \\
\hline 5. & $\begin{array}{l}\text { L. leucocephala } \\
\text { extract } 200 \mathrm{mg} / \mathrm{kg} \mathrm{BW}\end{array}$ & $96.20 \pm 3.397^{*,+}$ & $4.80 \pm 0.374^{*}$ & $190.20 \pm 4.913^{*}$ \\
\hline 6. & $\begin{array}{l}\text { L. leucocephala } \\
\text { extract } 400 \mathrm{mg} / \mathrm{kg} \mathrm{BW}\end{array}$ & $120.40 \pm 4.106^{*}$ & $3.80 \pm 0.374^{*}$ & $178 \pm 4.669^{*}$ \\
\hline
\end{tabular}

Data are presented as mean \pm SEM (One way ANOVA followed by Turkey's post hoc tests), for each group $n=5$. ${ }^{*}<0,05$ compared by $0,5 \% \mathrm{Na}$ CMC as control negative, $+p<0.05$ compared to loperamide $1 \mathrm{mg} /$ $\mathrm{kg} \mathrm{BW}$ as control positive.

as positive control. L. leucocephala also decreased the frequency of diarrhea (3.8-5.6 times) except at the extract (50 mg/kg BW) compared to the negative control did not differ much (6.8 times). The observation of $L$. leucocephala (400 mg/kg BW) had activity that was not significantly different from positive control ( $p>0.05$ ). Based on the observations, the investigation of the duration of diarrhea, the L. leucocephala groups with doses of 200 and $400 \mathrm{mg} / \mathrm{kg} \mathrm{BW}$ reduced the duration of diarrhea which when compared with the loperamide group did not differ significantly $(p>0.05)$, while in the $\mathrm{Na}$ CMC suspension group $0.5 \%$ obtained the longest time in this study.

Stool consistency and weight are determined by weighing the stool weight of animals and observing the stool consistency in the form of solid, mushy and watery stool. Ethanol extract of $L$. leucocephala seeds shows activity that reduced stool weight by varying the consistency of the stool at dependent manner dose. In the dose group, $400 \mathrm{mg} / \mathrm{kg} \mathrm{BW}$ had activity that was comparable to loperamide $(p>0.05)$. Observation results of stool consistency and weight are shown in Figure 1.

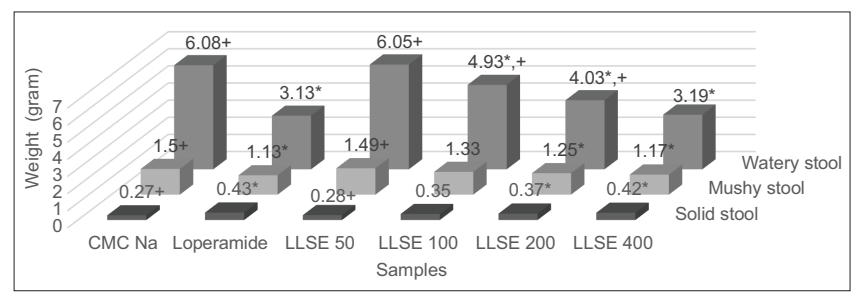

Figure 1: The weight of stool was differentiated according to the consistency of stool on diarrhea induced by castor oil index. Each bar shows the total number of watery, mushy, and solid stools of $L$. leucocephala seed extract (LLSE). Data presented as mean + SEM, $n=5$. ${ }^{*} p<0.05$ compared to negative control (Na CMC $0.5 \% \mathrm{Kg} / \mathrm{bw}$, $+p<0.05$ compared by loperamide $1 \mathrm{mg} / \mathrm{kg} \mathrm{bw}$ as positive control (One-way ANOVA followed by Turkey's post hoc tests)

\section{Gastrointestinal motility test}

L. leucocephala activity against intestinal motility tested by the intestinal transit method, where Chinese ink is an indicator for determining activity in inhibiting intestinal peristalsis, as shown in Figure 2. L. leucocephala shows its activity in inhibiting intestinal peristalsis in rats that have been induced by oleum

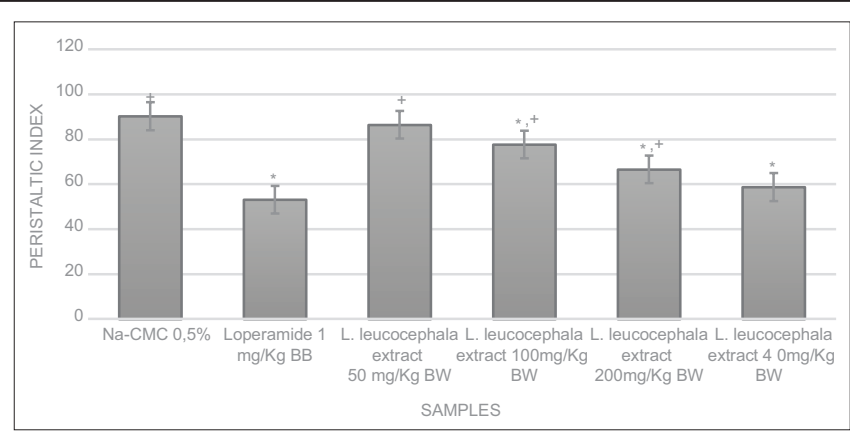

Figure 2: The peristaltic index of the extract ethanol L. leucocephala seeds activity on intestinal transit test of rat administered with Chinese ink. Data presented as mean + SEM, $n=5$. ${ }^{*} p<0.05$ compared to negative control ( $\mathrm{Na} \mathrm{CMC} 0.5 \%$ ), $+p<0.05$ compared by positive control as loperamide $1 \mathrm{mg} / \mathrm{kg}$ bw (One-way ANOVA followed by Turkey's post hoc tests)

ricini in line with increasing doses. Based on the results of statistical analysis $L$. leucocephala dose $400 \mathrm{mg} / \mathrm{kg}$ (58.74 \pm 2.208$)$ BW showed activity comparable to loperamide $1 \mathrm{mg} / \mathrm{kg}$ bw $(53.15 \pm 1.792)$ as positive control $(p>0.05)$.

\section{Discussion}

Diarrhea is defined as defecation with formless or liquid stool with a frequency of more than 3 times in $24 \mathrm{~h}$ [3]. Investigation of antidiarrheal effects is carried out by observing the initial time of diarrhea, frequency of diarrhea, weight, and consistency of stool as well as the duration of diarrhea that occurs using oleum ricini (castor oil) as induction of diarrhea in rats. Castor oil which produces active metabolites in the form of ricinoleic acid can cause diarrhea by increasing peristaltic activity in the intestinal mucosa so that it will cause changes in the intestinal mucosal cell permeability to fluids and electrolytes [16]. Oleum ricini was given $1 \mathrm{~h}$ before administration of $L$. leucocephala extract. The investigation $L$. leucocephala is stated to have antidiarrheal activity, if the initial time of diarrhea is longer than the negative control and if the diarrhea is faster, then the antidiarrheal activity indicated was weak activity. Based on Table 1, it can be seen the change in the average time (minutes) of animals experiencing diarrhea in each treatment group. CMC-Na $0.5 \%$ suspension group showed the fastest average initial time of diarrhea compared to other groups and L. leucocephala dose $400 \mathrm{mg} / \mathrm{kg} \mathrm{BW}$ had significant activity $(p>0.05)$ with loperamide suspension as positive control.

Loperamide (loperamide hydrochloride) was used this study as a positive control group because it acts directly on opioid receptors in the circular and longitudinal intestinal mucosa. Similar to other $\mu$ receptor agonists, loperamide inhibits intestinal peristalsis and prolongs transit time in the digestive system. 
Loperamide also stimulates the reabsorption process and changes water and electrolyte transportation. Thus, loperamide can reduce the volume of stool and reduce fluid and electrolyte loss [17].

Investigation of the frequency of diarrhea performed that showed the more diarrhea occur, the antidiarrheal activity will be weaker, and vice versa the less the frequency of diarrhea, the antidiarrheal activity will be stronger. Based on Table 1, there was a change in the average frequency of diarrhea from each treatment group. Negative control group showed the highest average frequency of diarrhea. The L. leucocephala group showed the average frequency of diarrhea getting smaller with increasing doses. L. leucocephala extract of $400 \mathrm{mg} / \mathrm{kg}$ BW showed a smaller average frequency compared to other groups but did not differ significantly when compared to control positive group based on the results of statistical tests obtained.

The investigation of the $L$. leucocephala was declared to have an antidiarrheal effect if the stool weight obtained was smaller than the negative control group. The heavier the stool weight was gained, the antidiarrheal effect indicated was weak activity. The negative control group showed the heavier of stool compared to other treatment groups. L. leucocephala group decreased weight of watery stool.

The duration of diarrhea was investigated by observing the animal from the initial time of diarrhea with a watery or flaccid consistency until it returns to the stool with solid consistency. Negative control group showed the longest time compared to other groups. The L. leucocephala extract showed decreasing the duration of diarrhea at dose-dependent manner. The positive control group showed the shortest diarrhea time compared to other groups.

L. leucocephala antidiarrheal effect with the intestinal transit method, it was found that L. leucocephala has an antidiarrheal effect in inhibiting intestinal motility. L. leucocephala dose 400 mg/kg BW showed percent of peristaltic index comparable to positive control, where L. leucocephala dose $400 \mathrm{mg} / \mathrm{kg}$ BW reduced the percentage of distance travelled by Chinese ink marker and decrease the amount of watery stool compared to the negative control group. Chinese ink is used as an indicator to determine the movement of intestinal motility by observing how far it traverses in the small intestine [15].

In the previous studies, L. leucocephala was reported to contain secondary metabolites such as alkaloids, flavonoids, tannins, and steroids [6], [18] Some of these metabolites have antidiarrheal effects as antimotility, antisecretory, and antibacterial properties such as tannins, flavonoids, and saponins [19]. Tannin compounds contained in the extract can reduce peristalsis and intestinal secretions [20]. In addition, flavonoids are also known to inhibit gastrointestinal motility and electrolyte secretion [14], [21].

\section{Conclusion}

L. leucocephala seed of the ethanol extract decreased the onset of diarrhea, frequency of diarrhea, consistency, and weight of stool and duration of diarrhea in rats after induced by castor oil. In addition, the extract reduced gastrointestinal motility which indicated by value of peristaltic index. L. leucocephala has potential to be developed as new anti-diarrheal agent. However, further studies are required to elucidate its mechanisms to treat diarrhea.

\section{Acknowledgments}

This research was supported by the Ministry of Research, Technology, and Higher Education of the Republic of Indonesia through research Penelitian Tesis Magister year 2019.

\section{References}

1. Farthing $M$, Salam MA, Lindberg G, Dite $P$, Khalif I, SalazarLindo $\mathrm{E}$, et al. Acute diarrhea in adults and children: A global perspective. J Clin Gastroenterol. 2013;47(1):12-20. https://doi. org/10.1097/mcg.0b013e31826df662

PMid:23222211

2. Akuodor GC, Muazzam I, Usman-Idris M, Megwas UA, Akpan JL, Chilaka KC, et al. Evaluation of the antidiarrheal activity of methanol leaf extract of Bombax buonopozense in rats. Ibnosina J Med Biomed Sci. 2011;3(1):15-20. https://doi. org/10.4103/1947-489x.210845

3. Hardman JG, Limbird LE, Editors. Alfred goodman gilman, alih bahasa tim alih bahasa sekolah farmasi ITB In: Goodman and Gilman Dasar Farmakologi Terapi. Vol. 2. Jakarta: Penerbit EGC; 2012. p. 1009-12.

4. Corwin EJ. Handbook of Pathophysiology. Edisi Ketiga. Terjemahan Subekti. Jakarta: EGC; 2009.

5. Chowtivannakul P, Srichaikul B, Talubmook C. Antidiabetic and antioxidant activities of seed from Leucaena leucocephala (Lam.) de Wit. Agric. Natu. Resour. 2016;50:357-61. https://doi. org/10.1016/j.anres.2016.06.007

6. Zayed MZ, Wu A, Sallam S. Comparative phytochemical constituents of Leucaena leucocephala (Lam.) leaves, fruit, stem bark and wood branches growin in Egypt using GC-MS method coupled with multivariate stastical approaches. Bio Resour. 2019;14(1):996-1013.

7. Chanwitheesuk A, Teerawutgulrag A, Rakariyatham N. Screening of antioxidant activity and antioxidant compounds of some dible plants of Thailand. J Food Chem. 2005;92:491-7. https://doi.org/10.1016/j.foodchem.2004.07.035

8. Saucedo G, Alvarez FJ, Jimenez N, Arriaga A. Leucaena leucocephala as a supplement for milk production on tropical pastures with dual purpose cattle. Trop Anim Prod. 1980;5:1.

9. Nhereraa FV, Ndlovua LR, Dzowelab BH. Utilisation of Leucaena diversifolia, Leucaena esculenta, Leucaena pallida 
and Calliandra calothyrsus as nitrogen supplements for growing goats fed maize stover. Anim Feed Sci Technol. 1980;74:15-28. https://doi.org/10.1016/s0377-8401(98)00164-3

10. Bussman RW, Glenn A, Sharo D. Antibacterial activity of medical plants of Northen Peru can traditional applications provide leads for modern science. Indian J Tradit Knowl. 2010;9(4):742-3.

11. Gupta HK, Atreja PP. Influence of ferric chloride treated Leucaena leucocephala on metabolism of mimosine and 3-hydroxy 4(1h)-pyridone in growing rabbits. Anim Feed Sci Technol. 1998;74(1):45-55. https://doi.org/10.1016/ s0377-8401(98)00172-2

12. Khamseekhiew B, Liang JB, Wong CC, Jalan ZA. Ruminal and intestinal digestibility of some tropical legume forages. Asian Aust J Anim Sci. 2001;14(3):321-5. https://doi.org/10.5713/ ajas.2001.321

13. Di Carlo G, Autore G, Izzo AA, Maiolino P, Mascolo N, Viola P, et al Inhibition of intestinal motility and secretory by flavonoids in mice and rats: Structure activity relationships. J Pharm Pharmacol. 1993;45(12):1054-9. https://doi.org/10.1111/j.2042-7158.1993. tb07180.x

PMid:7908974

14. Kumar R. Chemical and biochemical nature of fodder tree tannins. J Agric Food Chem. 2011;31:1364-6.

15. Yuandani and Nazira. Evaluation of antidiarrheal effect of Artocarpus altilis (Park.) leaves in mice. Int Res J Pharm. 2018;9(12):53-6. https://doi.org/10.7897/2230-8407.0912292
16. Ammon HV, Thomas PJ, Phillips SF. Effects of oleic and ricinoleic acids on net jejunal water and electrolyte movement. Perfusion studies in man. J Clin Invest. 1974;53:374-9. https:// doi.org/10.1172/jci107569

PMid:11344549

17. Regnard C, Twycross R, Mihalyo M, Wilcock A. Loperamide. J Pain Symptom Manage. 2011;42(2):319-23. https://doi. org/10.1016/j.jpainsymman.2011.06.001 PMid:21703817

18. Zayed MZ, Sallam SMA, Shetta ND. Review article on Leucaena leucocephala as one of the miracle timber trees. Int J Pharm Sci. 2017;10(1):1-7. https://doi.org/10.22159/ijpps.2018v10i1.18250

19. Otshudi AL, Vercruysse A, Foriers A. Contribution to the ethnobotanical, phytochemical and pharmacological studies of traditionally used medicinal plants in the treatment of dysentery and diarrhoea in Lomela area, Democratic republic of congo (DRC). J Ethnopharmacol. 2000;71(3):411-23. https://doi. org/10.1016/s0378-8741(00)00167-7

PMid:10940578

20. Ashok PK, Upadhyay K. Tannins are astringent. J Pharmacogn Phytochem. 2012;1(3):45.

21. Sanchez de Medina F, Galvez J, Gonzalez M, Zarzuelo A, Barrett KE. Effects of quercetin on epithelial chloride secretion. Life Sci. 1997;61:2049-55. https://doi.org/10.1016/ s0024-3205(97)00863-1

PMid:9366512 